\title{
A Brief History of the $\beta$-Arrestins
}

\author{
Marc G. Caron ${ }^{1,2,3}$, Lawrence S. Barak ${ }^{1}$ \\ ${ }^{1}$ Department of Cell Biology Duke University Medical Center Durham NC USA \\ ${ }^{2}$ Department of Neurobiology Duke University Medical Center Durham NC USA \\ ${ }^{3}$ Department of Medicine Duke University Medical Center Durham NC USA
}

\begin{abstract}
Arrestins have now been implicated in the actions of virtually every $\mathrm{G}$ protein-coupled receptor (GPCR) for which they have been examined. Originally discovered for their role in the turnoff of visual perception, their newly discovered pleotropic functions in the cellular and physiological actions of GPCRs not only illuminate new mechanisms of signal transduction but also offer new avenues for therapeutic utility. Below, in this introductory chapter, we provide a short historical description and synopsis of how arrestins conceptually became associated with the function of GPCRs.
\end{abstract}

\section{Keywords}

$\beta$-Arrestins; GPCR; GPCR kinases; Desensitization; Endocytosis; Signaling; selectivity/bias; Therapeutics

\section{Historical Perspective of $\beta$-Arrestin Biology}

Arrestins were first discovered as a major protein component of the retinal photoreceptor region and originally called the "retinal S antigen" for their involvement in uveitis [1]. Subsequent work in the visual system in the early 1980s led to the idea that the protein was involved in the turnoff of light-activated rhodopsin [2]. At that time, the relationship between the visual system machinery and receptors for hormones and neurotransmitters was not yet fully appreciated. This interesting relationship became more obvious with the cloning of the $\beta 2$-adrenergic receptor ( $\beta 2 \mathrm{AR}$ ) in 1986, which revealed that the putative membrane topology of the $\beta 2 \mathrm{AR}$ was similar to that of rhodopsin [3]. Early biochemical work with photoaffinity labeled and/or purified $\beta 2 A R$ had demonstrated that phosphorylation of the $\beta 2 \mathrm{AR}$ by a kinase distinct from protein kinase A (PKA) might be involved in its desensitization process [4-6]. Subsequently, a purified candidate protein kinase — originally called $\beta 2$ - adrenergic receptor kinase or $\beta$ ARK1, and later renamed G protein-coupled receptor kinase 2 (GRK2) — was isolated from lymphoma cells lacking protein kinase $A$ and shown to inhibit bovine brain capable of inhibiting the $\beta 2 A R$ activation of $\mathrm{G}$ protein [7]. However, as the purity of this kinase preparation advanced, its $\beta 2 \mathrm{AR} / \mathrm{G}$ 
protein uncoupling activity was lost until the reconstituted mix was supplemented with purified retinal S antigen/visual arrestin [7, 8], suggesting a role for an arrestin-like protein in the regulation of non-visual GPCRs. Subsequent work in the field led to the eventual purification and/or cloning of two visual GPCR kinases (GRKs) $[9,10]$ and five non-visual GRKs [11-15], as well as the genes for two distinct visual arrestins (arrestin 1 and 4) [16, 17] and two non-visual arrestins alternatively referred to as $\beta$-arrestin 1 or arrestin 2 and $\beta$ arrestin 2 or arrestin $3[18,19]$. Further investigations established that GRKs and arrestins together were necessary not only to fully modulate the signaling function or "desensitization" of the $\beta 2 \mathrm{AR}$ but also the signaling function of other GPCRs [20, 22]. Moreover, it was established that while these two classes of visual and non-visual accessory proteins display similar functions, specificity of action as well as tissue specificity could be demonstrated [22].

Cellular work in the early 1990s began to investigate other possible roles for the GRK/ arrestin modulation of GPCRs. Following on the earlier observations that GPCRs became "desensitized" and internalized following prolonged agonist activation [23, 24], it was demonstrated that desensitized $\beta 2 \mathrm{AR}$ could co-localize within the same endocytic compartment as the transferrin receptor, suggesting that GPCRs internalization might use the same mediated endocytic machinery [25]. This observation was further corroborated when it was revealed that $\beta$-arrestin 2 played an essential role in the internalization of the desensitized $\beta 2 \mathrm{AR}$, functioning as an adaptor to the endocytic machinery [26, 27]. Interestingly, tagging $\beta$-arrestins with GFP provided not only a way to assess GPCR/ $\beta$ arrestin interactions and trafficking in real time but also a foundation for the development of various cellular reporters widely used today for GPCR ligand screening [28]. Subsequent observations with different GPCRs led to the rather unexpected idea at the time that GPCR/ arrestin interaction could initiate intracellular signaling cascades, distinct from the canonical G protein-mediated signals [29, 30]. Eventually, this provocative idea was further supported by the demonstration that a given ligand could bind to a given receptor and act as an agonist at $G$ protein signaling but an antagonist for $\beta$-arrestin interactions or vice versa $[31,32]$.

Finally, the relevance of the visual arrestin/ $\beta$-arrestin concept was further established by demonstrating an in vivo physiological relevance for GPCR/ $\beta$-arrestin interactions. Indeed, the absence of $\beta$-arrestin 2 in mice markedly enhanced the analgesic effects of the opiate agonist morphine while concomitantly eliminating the development of morphine induced tolerance as well as the life-threatening side effects of decreased respiration and gastrointestinal function [33-35].

To use a colloquial expression, "the rest is history." As is elegantly outlined in this collection of methodological essays, the breadth of techniques presented in this compendium speaks not only to multitude of ways in which GPCR/ $\beta$-arrestins can be studied in the context of protein/protein interactions but also in the potential functions these interactions can play in the normal and dysfunctional physiological contexts. 


\section{Implications of $\beta$-Arrestin for Improved Therapeutics}

Since the early 2000s, the breakthrough resolution of the crystal structure of the prototypical GPCRs like rhodopsin and $\beta 2 A R[36,37]$ as well as complexes of GPCRs with their G protein or $\beta$-arrestin signaling partners [38-41] has added an unprecedented level of sophistication in approaches to elucidate GPCR signaling mechanisms and developing new therapies. As case in point, the advent of molecular modeling and docking of millions of chemical structures onto the structure of GPCRs [42] combined with conventional cellular screening platforms has provided exciting new ways to develop novel receptor probes with exquisitely high affinity and specificity [43, 44]. The methodologies described in this collection of papers/essays become crucial for relating the molecular determinants underlying GPCR/ $\beta$-arrestin interactions to the experimental parameters that define a receptor's signal transduction network. Indeed, one of the most interesting and potentially significant aspects of the GPCR/ $\beta$-arrestin paradigm is the possibility to selectively target that interaction for therapeutic gain. GPCRs represent a large portion of the therapeutic landscape, but most drugs invariably have untoward side effects. While these unwanted effects have been commonly attributed to the promiscuous interaction of drugs with other GPCRs, a lack of selectivity of these agents for the distinct signaling modes of targeted receptors may significantly contribute to an unnecessary reduction in their therapeutic specificity. Our ability to now develop therapeutic agents that have improved selectivity or bias for either the $G$ protein or $\beta$-arrestin signaling pathways is bound to produce better therapies.

\section{Acknowledgments}

Work in the Caron/Barak group at Duke University has been supported by grants for the United States National Institutes of Health (5R37-MH073853, 5P30-DA029925, 4U19-MH082441, 1R33CA191198); a gift from the Pall Family Foundation and the Howard Hughes Medical Institutes (1992-2005).

\section{References}

1. Dorey C, Faure JP (1977) Isolation and characterization of a retinal antigen inducing experimental autoimmune uveo-retinitis. Ann Immunol (Paris) 128:229-232 [PubMed: 848878]

2. Pfister C, Chabre M, Plouet J, Tuyen VV, De Kozak Y, Faure JP, Kuhn H (1985) Retinal S antigen identified as the $48 \mathrm{~K}$ protein regulating light-dependent phosphodiesterase in rods. Science 228:891-893 [PubMed: 2988124]

3. Dixon RA, Kobilka BK, Strader DJ, Benovic JL, Dohlman HG, Frielle T, Bolanowski MA, Bennett CD, Rands E, Diehl RE, Mumford RA, Slater EE, Sigal IS, Caron MG, Lefkowitz RJ, Strader CD (1986) Cloning of the gene and cDNA for mammalian beta-adrenergic receptor and homology with rhodopsin. Nature 321:75-79 [PubMed: 3010132]

4. Stadel JM, Nambi P, Lavin TN, Heald SL, Caron MG, Lefkowitz RJ (1982) Catecholamine-induced desensitization of turkey erythrocyte adenylate cyclase. Structural alterations in the beta-adrenergic receptor revealed by photoaffinity labeling. J Biol Chem 257:9242-9245 [PubMed: 6125504]

5. Stadel JM, Nambi P, Shorr RG, Sawyer DF, Caron MG, Lefkowitz RJ (1983) Catecholamineinduced desensitization of turkey erythrocyte adenylate cyclase is associated with phosphorylation of the beta-adrenergic receptor. Proc Natl Acad Sci U S A 80:3173-3177 [PubMed: 6304694]

6. Strasser RH, Sibley DR, Lefkowitz RJ (1986) A novel catecholamine-activated adenosine cyclic 3', $5^{\prime}$-phosphate independent pathway for beta-adrenergic receptor phosphorylation in wild-type and mutant S49 lymphoma cells: mechanism of homologous desensitization of adenylate cyclase. Biochemistry 25:1371-1377 [PubMed: 3008828] 
7. Benovic JL, Strasser RH, Caron MG, Lefkowitz RJ (1986) Beta-adrenergic receptor kinase: identification of a novel protein kinase that phosphorylates the agonist-occupied form of the receptor. Proc Natl Acad Sci U S A 83:2797-2801 [PubMed: 2871555]

8. Benovic JL, Kuhn H, Weyand I, Codina J, Caron MG, Lefkowitz RJ (1987) Functional desensitization of the isolated beta-adrenergic receptor by the beta-adrenergic receptor kinase: potential role of an analog of the retinal protein arrestin (48-kDa protein). Proc Natl Acad Sci U S A 84:8879-8882 [PubMed: 2827157]

9. Lorenz W, Inglese J, Palczewski K, Onorato JJ, Caron MG, Lefkowitz RJ (1991) The receptor kinase family: primary structure of rhodopsin kinase reveals similarities to the beta-adrenergic receptor kinase. Proc Natl Acad Sci U S A 88:8715-8719 [PubMed: 1656454]

10. Weiss ER, Raman D, Shirakawa S, Ducceschi MH, Bertram PT, Wong F, Kraft TW, Osawa S (1998) The cloning of GRK7, a candidate cone opsin kinase, from cone- and rod-dominant mammalian retinas. Mol Vis 4:27-34 [PubMed: 9852166]

11. Benovic JL, DeBlasi A, Stone WC, Caron MG, Lefkowitz RJ (1989) Beta-adrenergic receptor kinase: primary structure delineates a multigene family. Science 246:235-240 [PubMed: 2552582]

12. Boekhoff I, Inglese J, Schleicher S, Koch WJ, Lefkowitz RJ, Breer H (1994) Olfactory desensitization requires membrane targeting of receptor kinase mediated by beta gamma-subunits of heterotrimeric G proteins. J Biol Chem 269:37-40 [PubMed: 8276821]

13. Premont RT, Macrae AD, Stoffel RH, Chung N, Pitcher JA, Ambrose C, Inglese J, MacDonald ME, Lefkowitz RJ (1996) Characterization of the G protein-coupled receptor kinase GRK4. Identification of four splice variants. J Biol Chem 271:6403-6410 [PubMed: 8626439]

14. Kunapuli P, Benovic JL (1993) Cloning and expression of GRK5: a member of the G proteincoupled receptor kinase family. Proc Natl Acad Sci U S A 90:5588-5592 [PubMed: 7685906]

15. Benovic JL, Gomez J (1993) Molecular cloning and expression of GRK6. A new member of the G protein-coupled receptor kinase family. J Biol Chem 268:19521-19527 [PubMed: 8366096]

16. Shinohara T, Dietzschold B, Craft CM, Wistow G, Early JJ, Donoso LA, Horwitz J, Tao R (1987) Primary and secondary structure of bovine retinal S antigen (48-kDa protein). Proc Natl Acad Sci U S A 84: 6975-6979 [PubMed: 3478675]

17. Craft CM, Whitmore DH (1995) The arrestin superfamily: cone arrestins are a fourth family. FEBS Lett 362: 247-255 [PubMed: 7720881]

18. Parruti G, Peracchia F, Sallese M, Ambrosini G, Masini M, Rotilio D, De Blasi A (1993) Molecular analysis of human beta-arrestin-1: cloning, tissue distribution, and regulation of expression. Identification of two isoforms generated by alternative splicing. J Biol Chem 268:9753-9761 [PubMed: 8486659]

19. Attramadal H, Arriza JL, Aoki C, Dawson TM, Codina J, Kwatra MM, Snyder SH, Caron MG, Lefkowitz RJ (1992) Beta-arrestin2, a novel member of the arrestin/beta-arrestin gene family. J Biol Chem 267:17882-17890 [PubMed: 1517224]

20. Lohse MJ, Andexinger S, Pitcher J, Trukawinski S, Codina J, Faure JP, Caron MG, Lefkowitz RJ (1992) Receptor-specific desensitization with purified proteins. Kinase dependence and receptor specificity of beta-arrestin and arrestin in the beta 2-adrenergic receptor and rhodopsin systems. $\mathbf{J}$ Biol Chem 267:8558-8564 [PubMed: 1349018]

21. Pippig S, Andexinger S, Daniel K, Puzicha M, Caron MG, Lefkowitz RJ, Lohse MJ (1993) Overexpression of beta-arrestin and beta-adrenergic receptor kinase augment desensitization of beta 2-adrenergic receptors. J Biol Chem 268:3201-3208 [PubMed: 8381421]

22. Gurevich VV, Dion SB, Onorato JJ, Ptasienski J, Kim CM, Sterne-Marr R, Hosey MM, Benovic JL (1995) Arrestin interactions with G protein-coupled receptors. Direct binding studies of wild type and mutant arrestins with rhodopsin, beta 2 -adrenergic, and $\mathrm{m} 2$ muscarinic cholinergic receptors. J Biol Chem 270:720-731 [PubMed: 7822302]

23. Harden TK, Cotton CU, Waldo GL, Lutton JK, Perkins JP (1980) Catecholamine-induced alteration in sedimentation behavior of membrane bound beta-adrenergic receptors. Science 210:441-443 [PubMed: 6254143]

24. Stadel JM, Strulovici B, Nambi P, Lavin TN, Briggs MM, Caron MG, Lefkowitz RJ (1983) Desensitization of the beta-adrenergic receptor of frog erythrocytes. Recovery and characterization 
of the down-regulated receptors in sequestered vesicles. J Biol Chem 258:3032-3038 [PubMed: 6298219]

25. von Zastrow M, Kobilka BK (1992) Ligand-regulated internalization and recycling of human beta 2 -adrenergic receptors between the plasma membrane and endosomes containing transferrin receptors. J Biol Chem 267:3530-3538 [PubMed: 1371121]

26. Ferguson SS, Downey WE 3rd, Colapietro AM, Barak LS, Menard L, Caron MG (1996) Role of beta-arrestin in mediating agonist-promoted $\mathrm{G}$ protein-coupled receptor internalization. Science 271:363-366 [PubMed: 8553074]

27. Goodman OB Jr, Krupnick JG, Santini F, Gurevich VV, Penn RB, Gagnon AW, Keen JH, Benovic JL (1996) Beta-arrestin acts as a clathrin adaptor in endocytosis of the beta2-adrenergic receptor. Nature 383:447-450 [PubMed: 8837779]

28. Barak LS, Ferguson SS, Zhang J, Caron MG (1997) A beta-arrestin/green fluorescent protein biosensor for detecting G protein-coupled receptor activation. J Biol Chem 272:27497-27500 [PubMed: 9346876]

29. Luttrell LM, Ferguson SS, Daaka Y, Miller WE, Maudsley S, Della Rocca GJ, Lin F, Kawakatsu H, Owada K, Luttrell DK, Caron MG, Lefkowitz RJ (1999) Beta-arrestin-dependent formation of beta2 adrenergic receptor-Src protein kinase complexes. Science 283:655-661 [PubMed: 9924018]

30. DeFea KA, Zalevsky J, Thoma MS, Dery O, Mullins RD, Bunnett NW (2000) beta-arrestindependent endocytosis of proteinase-activated receptor 2 is required for intracellular targeting of activated ERK1/2. J Cell Biol 148:1267-1281 [PubMed: 10725339]

31. Azzi M, Charest PG, Angers S, Rousseau G, Kohout T, Bouvier M, Pineyro G (2003) Betaarrestin-mediated activation of MAPK by inverse agonists reveals distinct active conformations for G protein-coupled receptors. Proc Natl Acad Sci U S A 100:11406-11411 [PubMed: 13679574]

32. Wei H, Ahn S, Shenoy SK, Karnik SS, Hunyady L, Luttrell LM, Lefkowitz RJ (2003) Independent beta-arrestin 2 and $\mathrm{G}$ protein-mediated pathways for angiotensin II activation of extracellular signal-regulated kinases 1 and 2. Proc Natl Acad Sci U S A 100:10782-10787 [PubMed: 12949261]

33. Bohn LM, Lefkowitz RJ, Gainetdinov RR, Peppel K, Caron MG, Lin FT (1999) Enhanced morphine analgesia in mice lacking beta-arrestin 2. Science 286:2495-2498 [PubMed: 10617462]

34. Bohn LM, Gainetdinov RR, Lin FT, Lefkowitz RJ, Caron MG (2000) Mu-opioid receptor desensitization by beta-arrestin-2 determines morphine tolerance but not dependence. Nature 408:720-723 [PubMed: 11130073]

35. Raehal KM, Walker JK, Bohn LM (2005) Morphine side effects in beta-arrestin 2 knockout mice. J Pharmacol Exp Ther 314:1195-1201 [PubMed: 15917400]

36. Palczewski K, Kumasaka T, Hori T, Behnke CA, Motoshima H, Fox BA, Le Trong I, Teller DC, Okada T, Stenkamp RE, Yamamoto M, Miyano M (2000) Crystal structure of rhodopsin: a G protein-coupled receptor. Science 289:739-745 [PubMed: 10926528]

37. Rasmussen SG, Choi HJ, Rosenbaum DM, Kobilka TS, Thian FS, Edwards PC, Burghammer M, Ratnala VR, Sanishvili R, Fischetti RF, Schertler GF, Weis WI, Kobilka BK (2007) Crystal structure of the human beta2 adrenergic G-protein-coupled receptor. Nature 450:383-387 [PubMed: 17952055]

38. Rasmussen SG, DeVree BT, Zou Y, Kruse AC, Chung KY, Kobilka TS, Thian FS, Chae PS, Pardon E, Calinski D, Mathiesen JM, Shah ST, Lyons JA, Caffrey M, Gellman SH, Steyaert J, Skiniotis G, Weis WI, Sunahara RK, Kobilka BK (2011) Crystal structure of the beta2 adrenergic receptor-Gs protein complex. Nature 477:549-555 [PubMed: 21772288]

39. Zhou XE, Gao X, Barty A, Kang Y, He Y, Liu W, Ishchenko A, White TA, Yefanov O, Han GW, Xu Q, de Waal PW, Suino-Powell KM, Boutet S, Williams GJ, Wang M, Li D, Caffrey M, Chapman HN, Spence JC, Fromme P, Weierstall U, Stevens RC, Cherezov V, Melcher K, Xu HE (2016) X-ray laser diffraction for structure determination of the rhodopsin-arrestin complex. Sci Data 3:160021 [PubMed: 27070998]

40. Komolov KE, Du Y, Duc NM, Betz RM, Rodrigues J, Leib RD, Patra D, Skiniotis G, Adams CM, Dror RO, Chung KY, Kobilka BK, Benovic JL (2017) Structural and Functional Analysis of a beta2-Adrenergic Receptor Complex with GRK5. Cell 169(407-421):e416 
41. Cahill TJ 3rd, Thomsen AR, Tarrasch JT, Plouffe B, Nguyen AH, Yang F, Huang LY, Kahsai AW, Bassoni DL, Gavino BJ, Lamerdin JE, Triest S, Shukla AK, Berger B, Little J t, Antar A, Blanc A, Qu CX, Chen X, Kawakami K, Inoue A, Aoki J, Steyaert J, Sun JP, Bouvier M, Skiniotis G, Lefkowitz RJ (2017) Distinct conformations of GPCR-beta-arrestin complexes mediate desensitization, signaling, and endocytosis. Proc Natl Acad Sci U S A 114:2562-2567 [PubMed: 28223524]

42. Shoichet BK, Kobilka BK (2012) Structure-based drug screening for G-protein-coupled receptors. Trends Pharmacol Sci 33:268-272 [PubMed: 22503476]

43. Manglik A, Lin H, Aryal DK, McCorvy JD, Dengler D, Corder G, Levit A, Kling RC, Bernat V, Hubner H, Huang XP, Sassano MF, Giguere PM, Lober S, Da D, Scherrer G, Kobilka BK, Gmeiner P, Roth BL, Shoichet BK (2016) Structure-based discovery of opioid analgesics with reduced side effects. Nature 537:185-190 [PubMed: 27533032]

44. Wang S, Wacker D, Levit A, Che T, Betz RM, McCorvy JD, Venkatakrishnan AJ, Huang XP, Dror RO, Shoichet BK, Roth BL (2017) D4 dopamine receptor high-resolution structures enable the discovery of selective agonists. Science 358:381-386 [PubMed: 29051383] 